\title{
HUBUNGAN KAUSALITAS INTELECTUAL CAPITAL, PRODUKTIVITAS DAN NILAI PASAR DALAM SATU KONTINUM
}

\author{
Oleh : \\ Saiful Anam \\ (Dosen STIE Al-Anwar Mojokerto)
}

\begin{abstract}
Abstrak
Intellectual Capital diakui sebagai komponen bisnis dan sumber daya strategis untuk memperoleh dan mempertahankan persaingan pada perusahaan. Resource-based view menyatakan bahwa intellectual capital merupakan sumber daya perusahaan yang memegang peranan penting dalam mengembangkan strategi dengan cara mengetahui kapabilitas yang diperlukan oleh perusahaan. Oleh karena intellectual capital penting bagi perusahaan maka perusahaan memerlukan informasi mengenai intellectual capitalnya. Disamping itu pengelolaan intellectual capital yang efektif dan efisien akan mendorong pertumbuhan perusahaan yang nantinya akan dapat meningkatkan produktivitas dan nilai pasar perusahaan. Tujuan utama dari penelitian ini adalah untuk menguji dan menganalisis pengaruh intellectual capital terhadap produktivitas nilai pasar pada perusahaan manufaktur. Sampel dalam penelitian ini berjumlah 48 perusahaan yang listing di Bursa Efek Indonesia periode tahun 2005-2007 dengan menggunakan metode purposive sampling. Data penelitan yang diperoleh dianalisis dengan mnggunakan teknik deskriptif dan diuji dengan menggunakan regresi linier berganda. Hasil penelitian menunjukkan bahwa intellectual capital berpengaruh positif terhadap produktivitas dan nilai pasar. Begitu juga pengaruh intellectual capital terhadap nilai pasar yang melalui oleh produktivitas memberikan hasil yang juga positif. Hal ini berarti produktivitas mempererat hubungan secara positif antara intellectual capital terhadap nilai pasar.
\end{abstract}

Kata Kunci : Intellectual Capital, Produktivitas, Nilai pasar.

\section{Latar Belakang}

Dalam era globalisasi sekarang ini, dunia usaha mengalami perubahan yang sangat cepat, sehingga perusahaan harus bisa menyesuaikan diri dengan menyusun strategi yang selaras perubahan lingkungan bisnis. Untuk dapat berdaya saing, perusahaan harus meningkatkan keunggulannya dan juga memanfaatkan aktiva yang dimiliki secara optimum. Aktiva bisa dijadikan sebagai dasar dalam menilai perusahaan. Aktiva terdiri dari aktiva berwujud (tangible asset) dan aktiva tidak berwujud (intangible asset). Aktiva tidak berwujud diantaranya adalah intellectual capital yang terdiri dari customer capital, human capital dan structural capital.

Pada era sekarang perusahaan mulai memberikan perhatian serius tentang masalah bagaimana mengelola aset untuk dijadikan salah satu penggerak kemajuan bisnis dalam usaha meningkatkan kinerja perusahaan. Hal ini terlihat dari perkembangan dunia bisnis saat ini yang dikarakteristikkan oleh fenomena seperti e-business, globalisasi, tingkat daya saing yang lebih tinggi, evolusi teknologi baru yang cepat, tingkat kepekaan konsumen yang semakin cepat terhadap mutu produk dan layanan serta perubahan struktur ekonomi.

Intellectual capital diakui sebagai faktor yang dinilai penting dalam meningkatkan kekayaan perusahaan. Menurut Itami dalam Goh (2005) intellectual capital sebagai aset yang tidak berwujud (intangible assets) yang meliputi teknologi 
khusus, informasi pelanggan, nama merek, reputasi dan budaya perusahaan yang lainnya sangat berkontribusi terhadap kekuatan kompetitif perusahaan. Dari banyak penelitian, terdapat beberapa pengukuran mengenai pengukuran intellectual capital, dan untuk penelitian ini menggunakan pengukuran intellectual capital yang dilakukan oleh Pulic dalam Bounfour dan Edvinsson (2005: 202-203) yaitu dengan menggunakan perhitungan VAIC $^{\mathrm{TM}}$ yang merupakan sebuah indikator dengan menitikberatkan pada efisiensi total perusahaan atau kemampuan intelektualanya dengan beberapa indikator yang digunakan terdiri dari: Value-Added Human Coefficient (VAHU), Structural Value-Added (STVA), Value-Added Capital Coefficient (VACA).

Penelitian Berglund et al., (2002), menemukan adanya hubungan positif antara intellectual capital dan nilai pasar perusahaan. Hal tersebut berbeda dengan penelitian yang dilakukan oleh Fifer dan William (2003), yang menemukan adanya hubungan negatif intellectual capital terhadap nilai pasar perusahaan. Sedangkan studi yang dilakukan oleh Chen et al., (2005), menemukan bahwa perusahaan yang tingkat efisiensi intellectual capital nya baik akan dapat meningkatkan produktifitas, profitabilitas dan nilai pasar.

Dengan mendasarkan pada model penelitian Bontis (Bontis, et al., 2000), peneliti mencoba untuk melakukan modifikasi model dengan memasukkan variabel baru yaitu nilai pasar melalui produktivitas yang menunjukkan bahwa peran intellectual capital (human capital, customer capital, dan structural capital) memiliki pengaruh terhadap nilai pasar.

\section{Rumusan Masalah}

Adanya keterbatasan mengenai intellectual capital di Indonesia terutama di Bursa Efek Indonesia, sehingga kemudian memberikan pemikiran peneliti mengangkat permasalahan dalam penelitian ini yaitu 1) Apakah intellectual capital berpengaruh terhadap produktivitas?, 2) Apakah intellectual capital berpengaruh terhadap nilai pasar?, 3) Apakah intellectual capital berpengaruh terhadap nilai pasar melalui produktivitas?.

\section{Kerangka Pemikiran}

Stewart (1997: 58) menyatakan intellectual capital merupakan informasi, kapabilitas organisasi untuk menciptakan dan mengimplementasikan pengetahuan. Menurut Mc Connachie (1997) intellectual capital menunjukkan pengetahuan yang ditransformasikan menjadi sesuatu yang bernilai bagi perusahaan.

Society of Management Accountants Canada (SMAC, 1998 dan Pablos, 2003) mendefinisikan intellectual capital sebagai pengetahuan yang dimiliki oleh manusia yang kemudian masuk kedalam perusahaan yang akan menghasilkan keuntungan dimasa yang akan datang bagi perusahaan. Intellectual capital dianggap penting karena mengakui adanya pergeseran dari era industri ke era informasi, mengakui bahwa kontributor utama pada nilai perusahaan adalah aktiva tak berwujud, serta mengakui bahwa pengetahuan dan informasi terus berkembang.

Pada dasarnya, untuk mengelola intellectual capital adalah mencakup kegiatan yang bisa mencari, menumbuhkan, menjual dan membagikan informasi, pengetahuan dan solusi (Hidayat, 2000). Kegiatan tersebut sebenarnya termasuk tugas ekonomi yang paling penting dalam bisnis, masalahnya adalah bahwa aset intelektual tidaklah nyata sehingga banyak pemimpin dan manajer perusahaan cenderung mengabaikan aset intelektual yang sebenarnya memiliki nilai yang cukup berharga bagi perusahaan. Dengan demikian, dapat dikatakan bahwa intellectual capital mencakup lebih luas dari pengetahuan yang dapat memberikan manfaat bagi perusahaan. Kriteria manfaat harus dikaitkan dengan tersedianya pasar yang mengkonsumsi barang atau jasa yang diproduksi 
oleh perusahaan. Jika pasar ternyata tidak responsif terhadap barang atau jasa yang dihasilkan maka praktis pengetahuan tersebut tidak ada manfaat.

Saat ini untuk menuju ekonomi yang baru, perusahaan bisa melakukan investasi pada sumber daya modal fisik dan finansial serta sumber daya baru. Modal manusia ( human capital) jika dianggap oleh perusahaan sebagai sebuah investasi maka Return On Investment (ROI), nilai serta intellectual capital akan meningkat. Akan tetapi tidak semua karyawan bisa dikatakan human capital, karena hanya karyawan yang memiliki pengetahuan dan keahlian yang dapat memberikan nilai lebih bagi perusahaan. Untuk sumber daya modal fisik dan finansial serta sumber daya baru, dapat mencapai nilai melalui aktivitasnya, karena penciptaan nilai (value creation) menjadi tujuan bagi setiap perusahaan.

Intellectual capital merupakan sumber daya yang lebih berpotensi memberikan keunggulan bersaing dari pada intangible resources. Menurut Halawi et al., (2005), pengembangan dan pengelolaan intangible resources tergantung pada knowledge-based resources mencakup semua kemampuan intelektual dan pengetahuan yang dimiliki oleh karyawan, dan juga kapasitas untuk belajar memperoleh informasi baru. Beberapa cara yang dilakukan oleh perusahaan untuk mengembangkan dan meningkatkan knowledgebased resources dalam diri karyawan, diantaranya memberikan training, education, rewards dan membentuk term yang solid (Jackson et al., 2003: 10).

Pulic (1999), menganalisis bahwa intellectual capital dan sumber daya sangat penting bagi perusahaan. Penelitian yang dilakukan oleh Pulic dilakukan dengan mengukur efisiensi intellectual capital dengan modal fisik, yang hasilnya bahwa intellectual capital menciptakan nilai tambah yang besar bagi perusahaan. Hasil penelitian Pulic sangat konsisten dengan hasil penelitian Pena (2002), yang mengatakan bahwa intellectual capital tidak hanya membantu menjelaskan kinerja perusahaan besar tetapi juga perusahaan yang baru berdiri.

Pengukuran intellectual capital yang dilakukan oleh Pulic dalam Bounfour dan Edvinsson (2005: 202-203) menggunakan perhitungan Value-Added Intellectual Coefficient (VAIC $^{\mathrm{TM}}$ ). Perhitungan VAIC ${ }^{\mathrm{TM}}$ menurut Pulic (2000), merupakan sebuah indikator yang menitikberatkan pada efisiensi total perusahaan atau kemampuan intelektualnya dengan beberapa indikator yang digunakan yaitu: Capital Employed yang terdiri dari Physical Capital, Human Capital, dan Structural Capital.

Pulic (1998), menyatakan bahwa semakin tinggi koefisien $\mathrm{VAIC}^{\mathrm{TM}}$, maka semakin baik pula efisiensi nilai tambah dari total sumber daya perusahaan yang bersangkutan. Menurut Pulic (2000), VAIC ${ }^{\mathrm{TM}}$ merupakan sebuah indikator yang menitikberatkan pada efisiensi total perusahaan atau kemampuan intelektualnya dengan beberapa indikator yang digunakan yaitu: Capital Employed yang terdiri dari Physical Capital, Human Capital, dan Structural Capital. Langkah pertama dalam menghitung VAHU + STVA + VACA adalah menentukan total Value Added (VA).

Perusahaan harus memiliki rencana dalam membangun kapabilitasnya yang perlu dirancang sedemikian rupa sehingga sesuai dengan kondisi yang ada. Keunggulan bersaing yang berkesinambungan itu akan meningkat jika perusahaan memiliki produktivitas yang lebih tinggi daripada pesaingnya, sehingga usaha tersebut harus melalui usaha formal atau menjadi bagian dari operasional perusahaan, dari hal itu intellectual capital yang memberikan keunggulan kompetitif yang baik sangat penting untuk pencapaian produktivitas yang lebih tinggi yang berbeda dari pesaing perusahaan (Banker, 1989: 530).

Menurut Pulic (2000), pentingnya intellectual capital merupakan elemen yang paling strategik dalam organisasi perusahaan, yang harus diakui dan diterima oleh managemen perusahaan untuk meningkatkan produktivitas kerja yang mempengaruhi aktifitas perusahaan. Peningkatan produktivitas dapat dicapai dengan menekan biaya 
termasuk dalam memanfaatkan human capital dan meningkatkan keluaran sebesarbesarnya.

Menurut Stewart (1997), intellectual capital merupakan hal yang sangat penting dalam perusahaan. Apabila pengolahannya baik maka biaya dapat dibuat seefektif dan seefisien mungkin, yang nantinya akan membuat produktivitas tenaga kerja baik akan berdampak pada perusahaan dan kepuasan pelanggan serta berpendapat bahwa intellectual capital yang bersifat struktural dianggap sebagai modal pengetahuan apabila aset tersebut dapat membantu meningkatkan produktivitas dan inovasi perusahaan.

Intellectual capital telah diakui sebagai sumber daya yang penting yang dapat memberikan manfaat bagi terciptanya efisiensi, efektivitas dan inovatif perusahaan. Hartono (2002), mengatakan bahwa penghasil kekuatan pada perusahaan modern lebih banyak dari intelektual dan kecakapan dalam memberikan pelayanan daripada hard assets seperti tanah, gedung, dan peralatan lainnya. Misalnya saja perusahaan Coca Cola yang mengalami kesuksesan salah satunya karena digerakkan oleh kemampuannya dalam mengelola dan menggunakan intellectual capital untuk menciptakan keunggulan bersaing, yang pada akhirnya memberikan manfaat yang besar bagi pemegang saham.

Pentingnya intellectual capital sebagai intangible asset perusahaan juga ditunjukkan dengan adanya gap yang besar antara nilai pasar perusahaan dan nilai bukunya. Stewart (1998: 247-248), menyatakan bahwa jika nilai sebuah perusahaan lebih besar dari nilai yang dimiliki pemegang saham, maka bisa untuk mengaitkan selisihnya pada intellectual capital yang merupakan aset perusahaan. Menurut Tseng et al., (2005), ada beberapa faktor yang dapat mempengaruhi kenaikan nilai pasar perusahaan antara lain, human capital, structural capital, external capital dan financial performance.

Hubungan intellectual capital dengan nilai pasar juga diteliti oleh Chen et al., (2005), pada perusahaan di Taiwan, yang menyatakan bahwa intellectual capital diakui sebagai suatu strategi aset yang menggerakkan nilai perusahaan. Penelitian ini menggunakan VAIC sebagai ukuran kemampuan perusahaan dalam menghubungkan ketiga komponen VAIC, yaitu Value-Added Capital Coefficient (VACA), Value-Added Human Coefficient (VAHU), Structural Value-Added (STVA). Hasil penelitian ini membuktikan bahwa intellectual capital mempunyai dampak positif terhadap nilai pasar dan investor memberikan nilai pada perusahaan memiliki capital effeciency intellectual yang lebih baik.

Penelitian mengenai intellectual capital dilakukan oleh Bontis (2000), dimana dengan intellectual capital yang merupakan faktor utama yang dapat meningkatkan nilai pasar suatu perusahaan yang berasal dari kemampuan berproduksi suatu perusahaan sampai pada loyalitas pelanggan terhadap perusahaan serta dapat diperoleh dari budaya pengembangan perusahaan maupun kemampuan perusahaan dalam memotivasi karyawannya sehingga produktivitas perusahaan dapat dipertahankan dan dapat meningkat.

Bontis (2005), juga menjelaskan bahwa modal intelektual dalam konteks bangsa atau masyarakat. Menurutnya dalam konteks ini, intellectual capital bersama dengan kekayaan/modal finansial, akan membentuk kekayaan/ kesejahteraan perusahaan, setara dengan konsep nilai pasar dari suatu perusahaan yang baik melalui peningkatan pertumbuhan produktivitas.

\section{Metode Penelitian}

Berdasarkan landasan teori dan rerangka konseptual penelitian yang telah diajukan, dalam penelitian ini menggunakan variabel, yaitu :

1. Variabel independent (bebas) yaitu :

IC (intellectual capital), (X)

2. Variabel dependent (terikat), yang meliputi : 
a. Produktivitas (Y1)

b. Nilai pasar (Y2)

3. Variabel intervening yaitu :

Produktivitas, merupakan variabel intervening antara IC dengan nilai pasar.

Intellectual capital (X). Intellectual capital diukur dengan menggunakan pengukuran Value Added Intellectual Coefficient $\left(\mathrm{VAIC}^{\mathrm{TM}}\right.$ ), yaitu sebuah indikator yang menitikberatkan pada efisiensi total perusahaan atau kemampuan intelektualnya. VAIC ${ }^{\mathrm{TM}}$ diperoleh dengan menggabungkan (1). Value-Added Human Coefficient (VAHU), yaitu indikator efisiensi nilai tambah dari modal manusia; Structural Value-Added (STVA) yaitu indikator efisiensi nilai tambah dari modal strultural, Value-Added Capital Coefficient (VACA), yaitu indikator efisiensi nilai tambah dari modal yang digunakan, Sehingga dapat dihitung dengan menggunakan rumus sebagai berikut:

$\mathrm{VAIC}^{\mathrm{TM}}=\mathrm{VAHU}+\mathrm{STVA}+\mathrm{VACA}$

Dimana:

VAIC $^{\mathrm{TM}} \quad$ : Value added intellectual coefficient untuk perusahaan $i$.

VAHU : Value-Added Human Coefficient untuk perusahaan $i$.

STVA $\quad:$ Structural Value-Added untuk perusahaan $i$.

VACA : Value-Added Capital Coefficient untuk perusahaan $i$.

$$
\mathrm{VAHU}_{\mathrm{i}}=\mathrm{VA}_{\mathrm{i}} / \mathrm{HC}_{\mathrm{i}}
$$

Dimana:

VAHU $_{\mathrm{i}} \quad$ : Value-Added Human Coefficient untuk perusahaan $i$.

$V A_{\mathrm{i}} \quad:$ Value Added untuk perusahaan $i$.

$\mathrm{HC}_{\mathrm{i}} \quad$ : Human Capital untuk perusahaan $i$.

$\mathrm{HC}_{\mathrm{i}} \quad$ : Total pengeluaran untuk karyawan

$$
\mathrm{VA}=\mathrm{OP}+\mathrm{EC}+\mathrm{D}+\mathrm{A}
$$

Dimana:

VA (Value Added) : merupakan total indikator obyektif dari kesuksesan yang menunjukkan kemampuan perusahaan dalam menciptakan nilai yang perlu untuk investasi dan sumber daya.

OP (Operational Profit) : merupakan keseluruhan pendapatan yang berasal dari semua produk dan jasa yang dijual dipasar.

EC (Employee Cost) : merupakan beban atau biaya yang tercatat pada laporan laba rugi perusahaan pada tahun yang bersangkutan.

$\mathrm{D}$ (Depreciation)

A (Amortization)

: merupakan beban penyusutan yang tercatat pada laporan laba rugi perusahaan pada tahun yang bersangkutan.

: Alokasi sistematis atas jumlah yang dapat didepresiasi dari suatu aktiva selama masa manfaatnya.

$$
\mathrm{STVA}_{\mathrm{i}}=\mathrm{VA}_{\mathrm{i}} \cdot / \mathrm{SC}_{\mathrm{i}}
$$

Dimana:

STVA $_{i} \quad:$ Structural Capital Value-Added untuk perusahaan $i$.

$\mathrm{SC}_{\mathrm{i}} \quad$ :Structural Capital untuk perusahaan $i$.

$\mathrm{VA}_{\mathrm{i}} \quad$ : Value Added untuk perusahaan $i$.

$$
\mathrm{SC}_{\mathrm{i}}=\mathrm{VA}_{\mathrm{i}}-\mathrm{HC}_{\mathrm{i}}
$$

Dimana:

$\mathrm{SC}_{\mathrm{i}} \quad$ : Structural Capital untuk perusahaan $i$.

$\mathrm{VA}_{\mathrm{i}} \quad$ : Value Added untuk perusahaan $i$. 
$\mathrm{HC}_{\mathrm{i}} \quad$ : Human Capital untuk perusahaan $i$.

Dimana:

$\mathrm{VACA}_{\mathrm{i}}=\mathrm{VA}_{i} / \mathrm{CE}_{\mathrm{i}}$

VACA $_{i} \quad$ :Value-Added Capital Coefficient untuk perusahaan $i$.

$\mathrm{VA}_{\mathrm{i}}$

: Value Added untuk perusahaan $i$.

$\mathrm{CE}_{\mathrm{i}} \quad$ : Capital Employee untuk perusahaan $i$.

$\mathrm{CE}_{\mathrm{i}} \quad$ : Nilai buku aktiva bersih

Produktivitas (Y1). Produktivitas menunjukkan kemampuan perusahaan dalam memanfaatkan sumber daya yang dimiliki untuk menghasilkan output tertentu, sehingga dapat diketahui apakah perusahaan tersebut produktif atau tidak.

Salah satu dalam pengukuran produktivitas perusahaan dengan mengukur rasio Total Assets Turn Over (TATO), yaitu rasio yang digunakan untuk mengukur kemampuan manajemen dalam menghasilkan pendapatan dari investasi dalam aktiva (Fraser dan Ormitson, 2004: 184). Rumus untuk menghitung TATO adalah sebagai berikut :

$$
\text { TATO }=\frac{\text { Total pendapatan }}{\text { Total aktiva }}
$$

Dimana:

TATO : Asset turnover yang merupakan rasio produktivitas.

Total Revenue : Merupakan total pendapatan yang diperoleh perusahaan pada tahun yang bersangkutan.

Total Assets : Merupakan nilai buku total aset yang dilaporkan pada laporan tahunan pada tahun yang bersangkutan.

Nilai pasar (Y3). Didalam perusahaan nilai pasar diberikan oleh investor, yang ditunjukkan melalui harga saham perusahaan. Harga saham di pasar akan langsung mencerminkan nilai perusahaan tersebut berupa nilai kapitalisasi pasar (Siauw Hong, 2005: 40). Menurut Goh (2005), nilai pasar merupakan nilai perusahaan yang dievaluasi oleh pasar. Nilai pasar diukur dengan Market-to-Book Value (MBV), yang dapat dirumuskan sebagai berikut :

$$
\text { MBV }=\frac{\text { Total Market Capitalization }}{\text { Total Net Assets }}
$$

Dimana :

MBV

: Merupakan rasio pengukuran nilai pasar perusahaan

Total Market Capitalization: Merupakan jumlah saham biasa yang beredar yang tercatat dalam laporan keuangan perusahaan pada tahun buku yang bersangkutan dikalikan dengan harga pasar saham tersebut.

Total Net Assets $\quad$ : Merupakan nilai buku total aset yang dilaporkan pada laporan tahunan pada tahun yang bersangkutan.

Produktivitas sebagai variabel intervening. Pengaruh IC terhadap nilai pasar melalui produktivitas, menunjukkan pengaruh tidak langsung antara IC terhadap nilai pasar. Untuk menguji pengaruh variabel intervening digunakan metode analisis jalur (path analysis), agar lebih jelasnya dapat digambarkan jalur hubungan variabel sebagai berikut : 


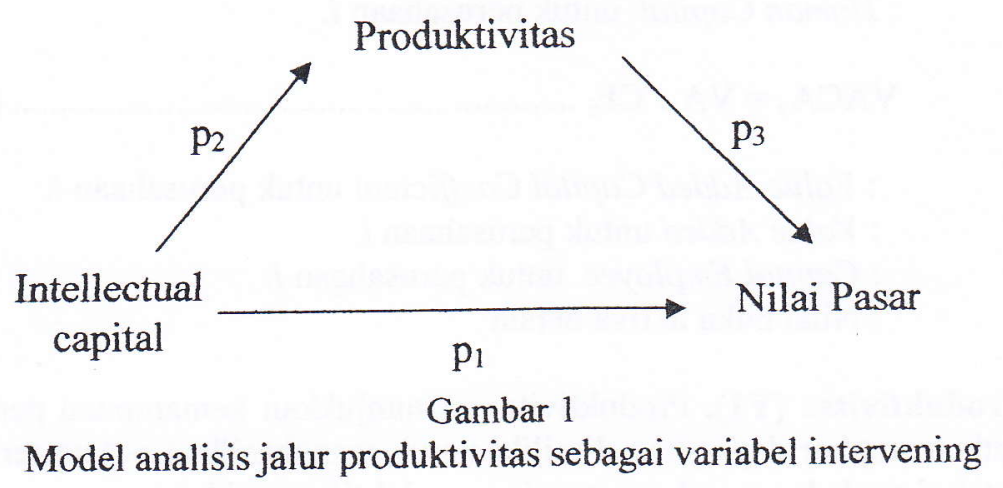

Persamaan regresi yang menunjukkan hubungan yang dihipotesiskan, sebagai berikut :

Produktivitas $=b_{1} I C+e_{1}$

Nilai pasar $=b_{1} I C+b_{2}$ produktivitas $+e_{2}$

Selanjutnya untuk mengetahui pengaruh tidak langsung dihitung :

Pengaruh langsung IC dengan produktivitas $\quad=p_{2}$

Pengaruh tidak langsung IC ke produktivitas ke nilai pasar $\quad=p_{2} \times p_{3}$

Populasi dalam penelitian ini adalah perusahaan-perusahaan yang terdaftar di Bursa Efek Indonesia (dahulu Bursa Efek Jakarta) selama periode penelitian yaitu antara tahun 2005 sampai dengan tahun 2007.

Metode pengambilan sampel yang digunakan adalah metode purposive sampling, yaitu suatu metode pemilihan sampel yang dilakukan berdasarkan kriteria-kriteria tertentu. Jumlah sampel dalam penelitian ini adalah 48 perusahaan dari total perusahaan manufaktur yang terdaftar di Bursa Efek Indonesia. Kriteria yang ditetapkan dalam pengambilan sampel ini adalah :

1. Perusahaan manufaktur yang listing terus menerus di Bursa Efek Indonesia tahun mulai tahun 2005 sampai tahun 2007.

2. Perusahaan manufaktur yang menerbitkan secara lengkap laporan keuangan maupun laporan tahunan yang berakhir pada tanggal 31 Desember selama periode pengamatan yaitu tahun 2005 sampai tahun 2007.

Hasil seleksi sampel yang diambil disajikan pada tabel 2 dibawah ini.

Tabel 1.

Hasil Seleksi Sampel

\begin{tabular}{|l|c|}
\hline \multicolumn{1}{|c|}{ Keterangan } & Jumlah \\
\hline Perusahaan yang listing di Bursa Efek Indonesia (dahulu Bursa Efek Jakarta) tahun 2005 & 323 \\
\hline Bukan perusahaan pemanufakturan & $(178)$ \\
\hline Perusahaan yang tidak listing berturut-turut mulai tahun 2005 sampai 2007 & $(19)$ \\
\hline Perusahaan yang tidak sesuai dengan kriteria purposive sampling & $(78)$ \\
\hline Total sampel & 48 \\
\hline
\end{tabular}

Sumber: Diolah penulis

Berdasarkan kriteria pemilihan sampel tersebut maka banyaknya sampel yang diambil dalam penelitian ini sebanyak 48 perusahaan yang listing di Bursa Efek Indonesia dan diharapkan mewakili dari populasi yang ada.

Jenis data yang digunakan dalam penelitian ini adalah data dokumenter, berupa laporan keuangan pada periode pengamatan tahun 2005 sampai tahun 2007. Sumber data yang digunakan dalam penelitian ini adalah data sekunder, yang berupa data keuangan yang dipublikasikan, Direktori Pasar Modal Indonesia (Indonesian Capital Market 
Directory), dan JSX Monthly report tahun 2005 sampai dengan tahun 2007, database Bursa Efek Indonesia (BEI) yang tersedia secara online.

Metode-metode analisis data yang dipergunakan dalam penelitian ini adalah :

1. Analisa kelayakan data Dalam pengujian analisa kelayakan data dilakukan dengan menghitung uji validitas, uji reliabilitas dan uji asumsi klasik.

2. Analisis Regresi

Uji regresi merupakan suatu teknik uji statistik yang dapat digunakan untuk menganalisa hubungan antara variabel dependen dengan variabel independen. Persamaan yang digunakan adalah sebagai berikut:

Produktivitas $=\mathrm{a}+\mathrm{b}_{1} \mathrm{IC}+\mathrm{e}_{1}$

Nilai Pasar $=a+b_{3} I C+e_{3}$

Nilai Pasar $=a+b_{4} I C+b_{5}$ Produktivitas $+e_{4}$

Dimana :

IC = Intellectual Capital

a $\quad=$ Intercept atau konstanta

e = Error term, yaitu tingkat kesalahan penduga dalam penelitian

Pengujian hipotesis yang dilakukan dalam penelitian ini menggunakan regresi linier, yang meliputi :

a. Uji t (Uji Parsial)

Uji parsial digunakan untuk menguji apakah variable independent secara individu berpengaruh terhadap variabel dependen.

$\mathrm{H}_{0}$ Diterima : jika thitung $<\mathrm{t}$ tabel (sig. $\left.>0,05\right)$

$\mathrm{H}_{0}$ tolak : jika thitung $>\mathrm{t}$ tabel $($ sig. $<0,05)$

b. Uji F (Uji Simultan)

Uji simultan digunakan untuk menguji persamaan 4 dan 5 , yaitu pengaruh intellectual capital terhadap nilai pasar dengan dengan menggunakan variabel intervening produktivitas dan profitabilitas.

$\mathrm{H}_{0}$ Diterima : jika $\mathrm{F}$ hitung $<\mathrm{F}$ tabel (sig. $>0,05$ )

$\mathrm{H}_{0}$ tolak : jika $\mathrm{F}$ hitung $>\mathrm{F}$ tabel $($ sig. $<0,05)$

Untuk pengolahan data digunakan program komputer Statistical Package Social Science (SPSS).

3. Analisis Jalur (Path Analysis)

Dalam penelitian ini, analisis jalur akan dipakai untuk menguji dan menganalisis hipotesis keempat dan kelima, yaitu adanya antara intellectual capital terhadap nilai pasar melalui produktivitas dan intellectual capital terhadap nilai pasar melalui profitabilitas.

Metode analisis lintasan atau analisis jalur (path analisis) digunakan untuk mengetahui pengaruh langsung dan pengaruh tidak langsung dari variabel bebas dan variabel terikat.

Persamaan untuk model analisis jalur pengaruh IC terhadap nilai pasar melalui produktivitas :

Produktivitas $=a+b_{1} I C+e_{1}$

Nilai Pasar $=a+b_{2} I C+b_{3}$ Produktivitas $+e_{2}$

Selanjutnya untuk mengetahui pengaruh IC terhadap nilai pasar melalui produktivitas dihitung dari perkalian $b_{1}$ (koefisien regresi IC) dengan $b_{3}$ (koefisien regresi produktivitas). 


\section{Hasil Penelitian}

\section{Pengaruh Intellectual Capital terhadap Produktivitas}

Intellectual capital dipertimbangakan sebagai faktor kritis bagi keunggulan bersaing dan kesuksesan perusahaan. Intellectual capital merupakan salah satu sumber daya perusahaan yang dapat menghasilkan nilai bagi perusahaan. Berdasarkan hasil analisis data yang telah dilakukan diketahui bahwa thitung sebesar 0,018 dengan signifikansi 0,986 maka Ho diterima dan Ha ditolak pada level of signifikan sebesar 0,05. Sehingga variabel intellectual capital memiliki pengaruh yang tidak signifikan terhadap produktivitas.

Pada penelitian ini sampel yang digunakan adalah perusahaan manufaktur, dimana perusahaan manufaktur mempunyai spesifikasi yang berbeda dengan jenis industri lain sehingga kebijakan yang dijalankan oleh manajemen, misalnya kebijakan depresiasi, tentunya juga akan berbeda. Selain itu jika dihubungkan dengan karakterisitik sampel dari industri perusahaan manufaktur yang dipakai diketahui bahwa perusahaan manufaktur cenderung tidak membutuhkan intellectual capital yang tinggi tetapi membutuhkan struktural capital yang tinggi, sehingga produktivitas yang ada relatif rendah. Terkait dengan hubungan kausalitas produktivitas terhadap nilai pasar, jumlah perusahaan manufaktur yang listing memiliki nilai produktivitas yang relatif rendah berkisar antara 0,026 sampai 2,71, pengujian menggunakan analisis regresi linier yang bersifat sensitif terhadap perubahan nilai pasar yang nilainya berfluktuasi sangat tinggi. Kondisi ini yang memberikan kontribusi terhadap hasil penelitian yang secara empiris produktivitas berpengaruh tidak kuat terhadap nilai pasar.

Hasil penelitian yang tidak signifikan ini dapat dikaitkan dengan aktivitas produksi sampel penelitian, dimana aktivitas produksi sampel dalam penelitian ini lebih didominasi oleh perusahaan makanan dan minuman serta industri outomotif. Artinya perusahaan tersebut memiliki aktivitas produksi lebih banyak menggunakan mesin daripada tenaga manusia dalam menghasilkan output suatu produk. Kondisi inilah yang menyebabkan kemampuan perusahaan dalam memanfaatkan sumber daya yang dimiliki untuk menghasilkan output tertentu tidaklah signifkan, karena sebagian besar aktivitas manusia dalam berproduksi tergantikan oleh mesin.

Hasil analisis sesuai dengan penelitian yang dilakukan oleh Stewart (1997), yang menyatakan intellectual capital merupakan hal yang sangat penting dalam perusahaan, dimana apabila pengolahannya baik maka biaya dapat dibuat seefektif dan seefisien mungkin, yang nantinya akan membuat produktivitas tenaga kerja baik akan berdampak pada perusahaan dan kepuasan pelanggan serta berpendapat bahwa intellectual capital yang bersifat struktural dianggap sebagai modal pengetahuan apabila aset tersebut dapat membantu meningkatkan produktivitas dan inovasi perusahaan.

\section{Pengaruh Intellectual Capital terhadap Nilai Pasar}

Pengelolaaan intellectual capital yang baik dan dilakukan secara effektif merupakan penciptaan nilai yang berdampak pada peningkatan nilai perusahaan.

Berdasarkan hasil penelitian diperoleh thitung sebesar 5,786 dengan signifikansi 0,000 maka Ho ditolak dan Ha diterima pada level of signifikan sebesar 0,05 . Sehingga variabel intellectual capital memiliki pengaruh yang signifikan terhadap nilai pasar.

Sedangkan nilai koefisien determinasi $\left(R^{2}\right)$ dalam penelitian ini diketahui diketahui sebesar 0,199. Yang menunjukkan seberapa besar variasi dari variabel terikat mampu dijelaskan oleh variasi bebas. Dengan demikian berarti $19,9 \%$ variasi dari nilai pasar dapat dijelaskan oleh intellectual capital. Sedangkan sisanya dijelaskan oleh variabel yang lain di luar model.

Hasil ini sesuai dengan penelitian yang dilakukan oleh Tseng dan Goh yang menghubungkan antara intellectual capital dengan nilai pasar perusahaan. Hasil 
penelitian ini menemukan adanya keterkaitan yang kuat antara intellectual capital dengan nilai pasar perusahaan.

\section{Pengaruh Intellectual Capital terhadap nilai pasar melalui produktivitas}

Berdasarkan hasil perhitungan regresi linier dapat diketahui hubungan tidak langsung dan total antara intellectual capital dan produktivitas terhadap nilai pasar, yaitu intellectual capital mempengaruhi produktivitas sebesar 0,000130 terdiri atas 0,001 terjadi secara langsung dan 0,000030 terjadi secara tidak langsung.

Jadi intellectual capital memiliki pengaruh yang positif terhadap nilai pasar melalui produktivitas, pengaruh tidak langsung melalui produktivitas ini terbukti signifikan. Hal ini dapat disimpulkan bahwa hubungan antara intellectual capital terhadap nilai pasar melalu produktivitas memberikan hasil positif dan signifikan.

Dalam penelitian ini dapat dikatakan bahwa intellectual capital merupakan alat produktivitas untuk meningkatkan nilai pasar, karena produktivitas akan mampu meningkatkan nilai pasar jika didukung oleh intellectual capital yang baik dalam suatu perusahaan. Hal ini dipahami karena dengan adanya intellectual capital yang baik, maka akan menciptakan individu-individu yang ahli dalam bekerja sesuai dengan bidangnya. Kemampuan, keahlian dan pengetahuan yang baik dari karyawan perusahaan tentunya akan berdampak pada hasil produktivitas yang tinggi dalam usaha mencapai hasil yang ditargetkan oleh perusahaan.

Hasil ini sesuai dengan penelitian yang dilakukan oleh Bontis (2000), dimana dengan intellectual capital yang merupakan faktor utama yang dapat meningkatkan nilai pasar suatu perusahaan yang berasal dari kemampuan berproduksi suatu perusahaan sampai pada loyalitas pelanggan terhadap perusahaan serta dapat diperoleh dari budaya pengembangan perusahaan maupun kemampuan perusahaan dalam memotivasi karyawannya sehingga produktivitas perusahaan dapat dipertahankan atau bahkan dapat meningkat.

\section{Simpulan}

Berdasarkan analisis penelitian telah dikemukakan, maka diperoleh kesimpulan dari penelitian ini sebagai berikut 1) Intellectual capital terhadap produktivitas memiliki pengaruh yang tidak signifikan, yang artinya bahwa pengaruh intellectual capital mempunyai hubungan terhadap produktifitas tetapi tidak kuat. Jika intellectual capital suatu perusahaan bisa memberikan keunggulan kompetitif yang baik dan meningkat maka produktifitas perusahaanpun juga akan meningkat tetapi tidak begitu besar, hal ini dikarenakan terjadinya aliran informasi yang kurang yang bisa mempengaruhi aktivitas perusahaan. 2) Intellectual capital terhadap nilai pasar mempunyai pengaruh yang signifikan, yang artinya bahwa pengaruh intellectual capital mempunyai hubungan dengan nilai pasar. Pada dasarnya intellectual capital merupakan hal yang penting bagi perusahaan, dimana jika pengelolaan intellectual capital dilakukan secara efektif maka akan meningkatkan nilai pasar perusahaan. 3) Intellectual capital memiliki pengaruh yang positif terhadap nilai pasar dengan produktivitas sebagai intervening, namun pengaruh tidak langsung melalui produktivitas ini terbukti signifikan, sedangkan pengaruh langsung produktivitas tidak terlalu kuat mempengaruhi nilai pasar. Hal ini berarti bahwa setiap peningkatan intellectual capital akan memberikan pengaruh terhadap kenaikan nilai pasar, meskipun di dalamnya terdapat variabel produktivitas yang menghubungkan keterkaitan antara intellectual capital dengan nilai yang mempunyai pengaruh kurang kuat. 


\section{Saran}

Berdasarkan dari hasil penelitian yang telah disimpulkan, maka peneliti dapat memberikan saran yang nantinya dapat bermanfaat bagi penelitian selanjutnya dimasa yang akan datang, antara lain :

1. Menggunakan pengukuran intellectual capital yang tidak hanya bersifat moneter.

2. Memperluas sampel penelitian pada industri lain yang belum diteliti dalam penelitian ini dengan periode jangka waktu yang lebih panjang untuk membuktikan adanya pengaruh intellectual capital terhadap produktivitas, nilai pasar pada perusahaan.

\section{Daftar Pustaka}

Banker, Rajivd, S.M. Datar, R.S Kaplan, 1989. productivity Measurement and Management Accounting, Journal of Accounting, Auditing, and Finance, Vol.4, No.4.

Berglund et al., 2002. "Intellectual Capital's Leverage on Market Value", inderscience.metapress.com/index/JLG2KDXGY4V550YC.pdf.

Bontis, Nick, William Chua Chong Keow. and Stanley Richardson, 2000. "Intellectual Capital and Business Performance in Malaysian Industries". Journal of Intellectual Capital. Vol. 1 No. 1,pp. 85-100.

Bounfour, Ahmed and Edvinsson, Leif, 2005. Intellectual Capital for Communities, U.S.: Elsevier Butterworth-Heinemann.

Chen, Ming-Chin et al., 2005. "An Empirical Investigation of The Relationship Between Intellectual Capital and Firms' Market Value and Financial Performance", Journal of Intellectual Capital, Vol. 6 No. 2, pp. 159-176.

Goh, Pek Chen, 2005. "Intellectual Capital Performance of Commercial Banks in Malaysia", Journal of Intellectual Capital, Vol. 6 No. 3,pp. 385-396.

Halawi et al., 2005. "Resource-Based View of Knowledge Management.for Competitive Advantage", The Electronic Journal of Kwwfedge Management, Vol. 3 Iss. 2, pp 75-86.

Hidayat, 2000. Peranan Sumber Daya Manusia yang Berbasiskan Modal Intelektual akan menjadi Asset Utama dalam Sistem Persaingan Bisnis Global. Orasi Ilmiah, Bandung, tanggal 28 Oktober.

Imam Ghozali, 2009, Aplikasi Analisis Multivariate dengan program SPSS, Cetakan IV, Semarang : Badan Penerbit Universitas Dipoengoro.

Jakson at al., 2003. "Managing Knowledge for Sustained Competitive Advantage", US: John Wiley \& Sons, Inc.

McConnachie. Gordon, 1997. "The Management of Intellectual Assets: Delis ermg Value to the Business". The Journal of Knowledge Management, Vol. 1 No. 1, September, pp. 56-62.

Pablos, Patricia Ordonez, 2003. "Evidence of Intellectual Capital Measurement from Asia. Europe and the Middle East". Journal of Intellectual Capital, Vol.3 No. 3, pp. 287-302.

Pulic, A. and Bornemann, M., 1999. The Physical and Intellectual Capital of Austrian Bank. http://www.measuring-ip.at/pares/public/bank/en-bank.html.

Pulic, Ante, 2000. "VAICTM - An Accounting Tool for 1C Management", International Journal Technology Management, Vol. 20 No. 5/6/7/8, pp. 702-714.

Siauw Hong et aL 2005, "Beyond Book Value: Lessons Learned from PTPN III in Creating Value", Jakarta: Ray Indonesia.

Stewart, Thomas A., 1997. Intellectual Capital:The New Wealth of Organization, New York: Doubleday/Currency.

Stewart, Thomas A., 1998. Modal Intelektual: Kekayaan Baru Organisasi, Jakarta: PT. Elex Media Komputindo. 
Tseng, Chun-Yao and Goo, Yeong-Jia James, 2005, "Intellectual Capital and Corporate Value in An Emerging Economy: Empirical Study of Taiwanese Mamufacturers", $R \& D$ Management, pp. 187-201.

Weston, J.F., and T.E. Copeland. 1995. Managemen Keuangan. Edisi kesembilan. Terjemahan. Jakarta: Bina Rupa Aksara. 